\title{
Роль психологічної культури вчителя у подоланні шкільної неуспішності учнів
}

Анотація. У статті аналізуються чинники, які лежали в основі успішності роботи педагогів-новаторів, висловлюеться припущчення, щзо ефект подолання шкільної неуспішності педагогами-новаторами досягався не стільки за рахунок ефективних нових методик, скільки був наслідком високої психологічної культури педагогів-новаторів. При иььому психологічна культура розуміється як інтегральне поєднання психологічної компетентності, ціннісно-смислового компоненту (ставлення до людей, світу, власної діяльності) та когнітивної складової (розвитку пізнавальних процесів та рефлексіі). В статті доводиться, щзо всі новатори були психологічно i педагогічно компетентними, вірили в здатність кожної дитини добре вчитися, любили своїх вихованиів, постійно самовдосконалювались і стимулювали розвиток учнів.

Ключові слова: психологічна культура, шкільна неуспішність, педагоги-новатори, ефективність навчання.

Проблема шкільної неуспішності належить до категорії «вічних», оскільки більше або менше відставання у навчанні певної дитини від більшості іï однокласників може викликатися надзвичайно широким спектром як внутрішніх, так і зовнішніх причин.

В історії вітчизняної психологічної думки інтерес до проблеми неуспішності хвилеподібно змінювався - від неймовірної зацікавленості на початку XX сторіччя до майже повного ігнорування цього явища 3 другої половини 30-х до початку 40-х років. Як це не прикро визнати, але зараз ми переживаємо черговий період втрати інтересу психологічної громадськості до питань шкільного неуспіху дитини. Так із 878 джерел, представлених у списку Електронної бібліотеки НАПН України (список був створений Sat Feb 2114:50:592015 ЕЕТ), лише 3 роботи певним чином можна пов'язати із розглядом проблем неуспішності [11; 13; 15]. Російський журнал «Мир психологии» за останні 5 років не містив жодної статті, присвяченої шкільній неуспішності, хоча регулярно публікує роботи з педагогічної психології. Навіть таке видання як «Психологическая наука и образование», яке переважно орієнтоване на висвітлення психологічних проблем загальноосвітньої школи, з 2010 по 2014 рік проігнорувало проблеми невстигаючих дітей. Виникає враження, що су- часні діти абсолютно всі високообдаровані та прекрасно встигають у школі. Та просте звертання до фактів показує, що це зовсім не так. Зокрема у Доповідній записці директора Українського центру оцінювання якості знань І. Л. Лікарчука Колегії Міністерства освіти і науки України «Про рівень навчальних досягнень випускників загальноосвітніх закладів України за результатами зовнішнього незалежного оцінювання 2014 р.» повідомляється: «У цілому рівень знань абітурієнтів, які вони виявили під час зовнішнього незалежного оцінювання, є невисоким... Результати тестування абітурієнтів дають підстави стверджувати, що вони виявили недостатній рівень знань із ключових розділів змісту навчальних дисциплін... Належний рівень знань своїх випускників забезпечують далеко не всі заклади так званого нового типу, котрі мають особливі умови фінансування та організації освітнього процесу: гімназії, ліцеї, колегіуми. Так, результати у діапазоні від 100 до 150 балів з української мови та літератури отримали лише $24 \%$ цьогорічних випускників гімназій; 3 математики $22 \%$ випускників ліцеїв; 3 історії України - $34 \%$ випускників колегіумів. Навіть із іноземних мов, вивченню яких у цих закладах мала б приділятися особлива увага, результати не можна вважати позитивними. Так, із англійської мови результати в діапазоні від 180 до 199,5 балів показали лише 
$16 \%$ випускників гімназій, $14 \%$ - випускників ліцеїв, $13 \%$ - випускників колегіумів. Із німецької мови результат в діапазоні від 100 до 150 балів показали більше 20\% випускників гімназій, близько $40 \%$ - випускників ліцеїв, $43 \%$ - випускників колегіумів... 25\% учасників тестування 3 англійської мови і $13 \%$ - 3 української мови та літератури навіть не розпочали виконання відкритого завдання тесту» [6].

Як бачимо, проблема неуспішності залишається достатньо гострою та потребує подальшого психологічного аналізу. При цьому, можливо, потрібно повернутись до вивчення феноменів, пов'язаних 3 подоланням неуспішності окремими педагогами, а саме до роботи вже призабутих «новаторів», та виявити місце психологічної культури у їх досягненнях. Психологічну культуру вчителя будемо розуміти як інтегральне поєднання психологічної компетентності, ціннісно-смислового компоненту (ставлення до людей, світу, власної діяльності), когнітивної складової (розвитку пізнавальних процесів та рефлексії) $[4 ; 8 ; 12 ; 14 ; 16]$.

Друга половина XX сторіччя у вітчизняній педагогіці позначилась появою цілої плеяди педагогів-практиків, які спробували подолати шкільну неуспішність як явище. Аналіз їх наробок проводили видатні педагоги і психологи того часу - В.В. Давидов, 3.І. Калмикова, М.М. Скаткін. В Україні грунтовний аналіз новаторської творчості здійснив Ю. З. Гільбух. Однак, як це не дивно, практично всі дослідники творчості новаторів, вітаючи прекрасні результати їх діяльності, не могли визначити реальне підгрунтя успішності роботи, і тому кожному 3 новаторів доводилось знову і знову доводити науковому і педагогічному товариству результативність своїх підходів до навчання. Викликав здивування і той факт, що високої результативності авторів нових методик не вдавалося досягти більшості палких послідовників. Так, покращання показників, і то досить значні, були, але не вдавалось головне - вирівнювання успішності всіх дітей, повне і беззастережне подолання відставання. На перший погляд могло здатися, що справа у складності самих ме- тодик - адже робота по-новому вимагала повної самовіддачі педагога, величезної витрати часу. Особливо важко було працювати за методикою В. Ф. Шаталова, за якою до кожного уроку творилися опорні сигнали, які потрібно було ще якось множити для кожного учня. Не слід забувати, що новатори творили в докомп'ютерну еру, в країні, де множильна техніка (хоча б той же ксерокс) перебувала під спеціальним контролем і звичайному вчителеві була просто недоступна. Цей фактор, звичайно, відігравав свою роль, але був не настільки вагомим, як це може здатись на перший погляд, оскільки з часом всі опорні сигнали Шаталова були видані типографським способом і кожен педагог міг вільно ними скористатись. У В.Ф. Шаталова з'явились сотні послідовників, але з часом їх захват змінився певною апатією і, як зазначає Ю. М. Меженко (учасник експерименту в СШ №5 м. Донецька в 1987-1991рр.): «Дивна справа: у 80-ті роки книги В.Ф. Шаталова були в дефіциті, учителі їхали (за свій рахунок!) в Донецьк, відкриваючи для себе нову методику, а зараз у школах працює покоління вчителів, яке знає про Шаталова лише 3 чуток (понаслышке)» [10]. Що ж було причиною того, що прекрасний індивідуальний досвід новаторів не став надбанням педагогіки в цілому, а залишився лише чудовим, але поодиноким експериментом, i чи дійсно був правий найпалкіший опонент В.Ф. Шаталова - доктор фізико-математичних наук О.В. Гладкий, який у далекому 1988 році писав: «...він (Шаталов) вносить у викладання дуже багато «інженерного». Навчальний процес у його класі нагадує сучасне виробництво з безвідмовно діючим конвеєром. I це імпонує людям технічного віку з їхнім культом технології. Вони не помічають, що «технологізація» несе в собі небезпеку знеособлення (обезличения)... навчання за умови масового впровадження» [5].

Щоб розібратись в успіхах новаторів і неуспіху поширення їх досвіду в цілому, повернемось у 80-ті роки минулого сторіччя і зупинемось на тих педагогічних ідеях, які відмічались і самими новаторами, 
і дослідниками їх творчості як системоутворюючі:

1. Педагогіка повинна стати педагогікою співробітництва, коли учитель поважає особистість учня і визнає його партнерську роль у навчальному процесі. Не можна змусити когось навчатися, треба створити такі умови, коли дитина сама захоче оволодіти знаннями.

2. Нові методи навчання повинні бути спрямовані на зацікавлення дитини, допомогу в оволодінні знаннями, попередженні помилок, подоланні страху перед помилками.

3. Педагог повинен вірити в себе і в своїх дітей $[1 ; 2 ; 3 ; 9 ; 17 ; 18 ; 19]$.

Самі ж запропоновані новаторами методи не були, як уже відмічалось вище, аж надто революційним. Так, аналізуючи доробок В.Ф. Шаталова, 3. І. Калмикова відмічала наступне:

1. «Шаталов не вносить суттєвих змін в зміст освіти, ...не винаходить нових психолого-дидактичних принципів навчання, не вимагає застосування якихось особливих, складних технічних засобів навчання... Він запропонував таку організаційно-методичну систему навчання, яка дозволяє... реалізувати цілий комплекс... психологодидактичних принципів і тим самим забезпечити набуття учнями глибоких, добре закріплених, оперативних знань і навичок та формування у них... цінних моральних якостей особистості...» [7, с. 4].

2. Основним елементом $є$ опорні сигнали - ОС, які являють собою наочну схему, в якій закодований основний зміст знань, що повинні бути засвоєні. Слід відмітити, що ОС (хоч і під іншими назвами) уже застосовувались у педагогічній практиці і до Шаталова.

3. Шаталову закидають, що він неправильно робить, даючи ОС у готовому вигляді, а не будує їх разом з дітьми на уроках. Калмикова заперечує - в ОС фактично представлений той мінімальний теоретичний матеріал, який має бути засвоєний, але подається цей матеріал в його суттєвих зв'язках і взаємовідносинах.
4. ОС дозволяють якнайкраще реалізувати в навчанні принцип крупноблочного введення теоретичних знань. Тут Калмикова підкріплює своє бачення важливості такої блочності посиланням на Занкова, Давидова, Ерднієва, а також робить такий психологічний пасаж: «3 психологічної точки зору розуміння передбачає встановлення смислових зв'язків між новими та добре засвоєними раніше знаннями» [7, с. 6].

5. Застосування різних кольорів в ОС полегшує диференціацію подібних (сходних) понять, виділення спільного методу їх аналізу, оперування ними.

6. Калмикова вважає одним із основних принципів методики Шаталова - засвоєння знань на основі їх багаторазового варіативного повторення [7, с. 6].

7. Методика Шаталова дозволяє реалізувати принцип гармонічного розвитку репродуктивного і продуктивного мислення $[7$, c. 7].

8. В методиці Шаталова успішно реалізується принцип поєднання постійного зовнішнього контролю за ходом засвоєння матеріалу і його оцінки з самоконтролем і самооцінкою.

9. Гуманізм як основа формування високоморальних якостей особистості школяра. Прекрасний психологічний клімат на уроці.

Аналіз, здійсненний Калмиковою, показує, що зовсім не методичні прийоми були головними в методиці Шаталова, а його шалене переконання у тому, що всі його учні все можуть.

В системі С. М. Лисенкової наголос теж робився на вивченні нового матеріалу «крупними блоками», ідеї «випереджаючого навчання» $\mathrm{i}$ тих же по суті опорних сигналах, які вона називала «опорними схемами». Та найважливішим елементом в системі С.М. Лисенкової були не методи, а попередження можливої помилки, передбачення труднощів і надання кожній дитині шансу отримання задоволення від процесу навчання. Лисенкова С. М. згадувала:

«Якось мені довелось взяти чужий клас... Хвилювалась: чи признають? Неза- 
баром діти відмітили: «Чому ви нас ніколи не лаєте? Чому так швидко проходить урок?»

Через місяць прийшла до мене на урок завуч, а потім сказала:

- Я знаю цей клас. Тут хто сидів під партою, хто стояв у кутку, хто за дверима - ніхто не вчився. Тепер же всі працюють, посміхатися стали! Як це вам вдалося?

- Це і є моя методика, - відповіла я» $[9$, c. 58].

Як бачимо С.М. Лисенкова чітко усвідомлювала, що іiі методика полягає головним чином у створенні атмосфери доброти та поваги до дитини, яка базувалась на внутрішньому переконанні, що немає такої навчальної задачі, з якою не зможе справитись ії вихованець.

Тих самих поглядів притримувався i Ш.О. Амонашвілі, проголошуючи ідею «гуманної педагогіки», постійного співробітництва в системі «учитель - учень». Методика викладання у нього виступає вторинним і навіть інколи здається абсолютно невартісним елементом. Головне - сама постать вчителя, його вплив на дитину. Ці переконання склались на основі власного досвіду, адже Амонашвілі в дитинстві пройшов складний шлях від тотального двієчника до відмінника, золотого медаліста. I це чудо створила одна любляча дітей вчителька Варвара Вардіашвілі. Наведемо досить розлогий, але надзвичайно важливий для розуміння суті проблеми невстигання уривок зі спогадів Шалви Олександровича, вміщений у його книзі «Як любити дітей».

Початок шкільного життя для Ш.О. Амонашвілі був дуже болісним. Школа відштовхувала його, а він відштовхував школу і не розумів, чому вчителі так ставляться до дітей, чи люблять їх взагалі. Уже дорослим, відомим вченим він писав: «Звичайно, вони любили всіх дітей... Любили, тому що повинні були любити... Любили авторитарно. Любили своїми заштампованими сірими уроками, безкінечними нудними домашніми завданнями і перевірками, викликами до дошки і виставлянням оцінок, любили своїм роздратуванням і погроза- ми, контрольними роботами і виправленням помилок, любили своїми образами... i викликами батьків, любили проходженням програми, успішності в процентах і дотриманням так званої усвідомлюваної дисципліни... Помітно було, що багато вчителів більше любили свою владу над нами, аніж нас самих. I ми відповідали на таку любов наших вчителів своєю «любов'ю»... зривали уроки, втікали з уроків, запасались шпаргалками, списували один в одного... обдурювали...» А потім сталось чудо: «Це дуже дивно. Я - круглий двієчник до сьомого класу, потім - круглий трієчник, а закінчив школу із золотою медаллю. Як це могло статися?

Отже, я в сьомому класі, це 1945-1946 навчальний рік. Ми дізнаємось, що грузинській мові і літературі нас буде вчити Варвара Вардіашвілі... Ми чули про неї всі учні із інших класів любили іiі. Розповідали про iï чудові уроки, про ï доброту й уважність, про те, як вона допомагає всім, говорили про іiї справедливість, про те, як вона захищає своїх учнів. «У неї неможливо не учитися», - говорили нам старшокласники.

Про неї розповідали легенди...

Сива, повненька, невисока на зріст, 3 м'якою і спокійною ходою... 3 чаруючою посмішкою, оксамитовим голосом, який ніколи не підвищувала, стримана, з лагідним, все розуміючим поглядом...

Настав день.

Ми чекали i вона увійшла до нас у клас.

- Добридень... - сказала вона тоном і вібраціями, які я через багато років буду згадувати і досліджувати... це була незвичайна лагідність, така довгоочікувана.

І ми відповіли їй не так, як вітались 3 іншими вчителями, а так само ніжно, тихо.

Потім вона сказала:

- Дякую.

...Вся школа звала іiі «Дейда Варо». Дейда в перекладі російською означає «тітонька», але семантика цього слова має трохи інший зміст - «мамина сестра». Дейда Варо для кожного їі учня була маминою сестрою. Це означало, що в ній жила 
турбота про кожного ii учня, кожен міг звернутись до неї по допомогу, підтримку, захист; кожен міг сподіватись, що знайде в ній співчуття, розуміння. Це означало навіть більше: Дейда Варо сама поспішала 3 допомогою, співчуттям, розумінням, сама вставала на захист того, хто потребував такої допомоги» [2]. I ця здатність розуміти і співчувати дітям творила чудеса - перетворюючи двієчників на відмінників.

Пам'ятаючи свій шкільний досвід i чудо, створене Варварою Вардіашвілі, Ш.О. Амонашвілі у своїх творах насамперед говорив не про методики навчання, а про стосунки педагога і дитини, ставлячи перед учителем першокласників-шестирічок завдання:

\section{І. Любити дітей:}

1. Любити дітей такими, які вони $€$.

2. Любити всіх - i лінивих, і пустунів, і тугодумів.

3. Любов повинна бути головним мотивом і стимулом педагогічної діяльності.

\section{II. Розуміти дітей.}

1. Діти маленькі, але проблеми у них великі.

2. Розуміти дітей означає стати на їх позицію, цінити їх почуття, рахуватись із ними.

\section{III. Бути оптимістами:}

1. Вірити в педагогіку.

2. Лише оптимізм вчителя надає сил дитині, пробуджує здатності, що дрімають.

3. Оптимізм вчителя має бути діяльним, коли педагог глибоко проникає у внутрішній світ дитини і залежно від цього шукає методичні шляхи для виховання навчання i розвитку. Діяльний (деятельный) оптимізм вимагає від педагога постійної творчості, безперервного пошуку [1, с. 87].
В. Ф. Шаталов,
С. М. Лисенкова, Ш.О. Амонашвілі були не схожими один на одного педагогами, які різними методами досягали однаково хороших результатів. Що ж стало джерелом їхнього успіху? Якби це були виключно їхні навчальні технології, то вони б працювали однаково ефективно в руках будь-якого грамотного педагога. Однак цього не сталось. Отже було ще щось, що перетворювало звичайну навчальну технологію на знаряддя досягнення високих результатів. I цим чимось могла бути висока психологічна культура педагогів-новаторів.

Повернемось до визначення психологічної культури вчителя і співвіднесемо іiі з тим, що знаємо про педагогів-новаторів:

- компетентність - як педагогічна, так і психологічна - у всіх дуже висока;

- ціннісно-смисловий компонент (ставлення до людей, світу, власної діяльності) розвинений прекрасно - позитивне ставлення до дітей, віра в їх сили, налаштованість на досягнення високих результатів у власній діяльності;

- когнітивна складова яскраво виражена - вічний пошук нового, стимуляція когнітивних здатностей — як власних, так і своїх вихованців.

Як бачимо досягнення педагогів-новаторів не тільки спиралися на розроблені ними методики викладання, а базувались на високій психологічній культурі і саме ця культура i була основним чинником прекрасних результатів їхньої роботи.

\section{Список використаних джерел:}

1. Амонашвили Ш.А. В школу с шести лет / Ш. А. Амонашвили // Педагогический поиск / Сост. Н. И. Баженова. - М. : Педагогика, 1987. — С. 9-56.

2. Амонашвили Ш.А. Как любить детей (опыт самоанализа) [Электронный ресурс]. — Донецк, 2010. - Режим доступа : http://nsportal.ru/gp/amonashvili-sha-kak-lyubit-detei-opytsamoanaliza-donetsk-2010

3. Амонашвили Ш.А. Психологические основы педагогики сотрудничества / Ш. А. Амонашвили // Книга для учителя. — К. : Освита, 1991. — 111 с.

4. Бодалев А.А. Личность и общение / А. А. Бодалев. - М. : Международная педагогическая академия, 1995. - $328 \mathrm{c.}$

5. Гладкий А.В. Что нужно учителю - педагогика и методика или наука и культура? [Электронный ресурс] / А. В. Гладкий. - Режим доступа : http://modernproblems.org.ru/ education/66-whatneed.html?showall=1 
6. Доповідна записка директора Українського центру оцінювання якості знань І. Л. Лікарчука Колегії Міністерства освіти і науки України «Про рівень навчальних досягнень випускників загальноосвітніх закладів України за результатами зовнішнього незалежного оцінювання 2014 р.» [Електронний ресурс]. — Режим доступу : http:/osvita.ua/doc/files/ news/442/44207/dopovidna_1.doc

7. Калмыкова 3. И. Предисловие / З.И. Калмыкова // Педагогическая проза: Из опыта работы школ г. Донецка / В. Ф. Шаталов. - М. : Педагогика, 1980 - С. 3-12.

8. Куликова Т.И. Классный руководитель: профессиональная компетентность и психологическая культура : монография / Т. И. Куликова. - Тула : Левша, 2008. - 164 с.

9. Лысенкова С.Н. Когда легко учиться / С.Н. Лысенкова // Педагогический поиск / Сост. Н.И. Баженова. - М. : Педагогика, 1987. — С. 56-100.

10. Меженко Ю.С. Организационно-методическая система В.Ф. Шаталова, или тезисный «методический ликбез» [Электронный ресурс] / Юрий Степанович Меженко. — Режим доступа : http://5fan.info/yfsrnabewpolotrujg.html

11. Мусіяка Н.І. Стратегії корекції емоційної сфери молодших школярів з різним рівнем навчальних досягнень [Електронний ресурс] / Наталія Іванівна Мусіяка // Проблеми сучасної психології : збірник наукових праць Кам’янець-Подільського національного університету імені Івана Огієнка, Інституту психології ім. Г.С. Костюка НАПН України. — № 15. - 2015. - С. 393-401. - Режим доступу : http://lib.iitta.gov.ua/view/creators/== $0420=043 \mathrm{E}=0436=0434=0435=0441=0442=0432==0435=043 \mathrm{D}==0441=044 \mathrm{C}=$ $=043 \mathrm{~A}==0430=3 \mathrm{~A}==0414=2 \mathrm{E}==0411=2 \mathrm{E}=3 \mathrm{~A}=3 \mathrm{~A} \cdot \mathrm{html}$

12. Рибалка В.В. Аксіологічні основи психологічної культури особистості : навч.-метод посібник / В. В. Рибалка // Ін-т пед.освіти і освіти дорослих; Ін-т обдарованої дитини; АПН і МОН України, Укр. наук.-метод. центр практ. психології і соц. роботи. - К., 2009. $-326 \mathrm{c}$.

13. Рождественська Д.Б. Діагностика провідного когнітивного стилю дітей з труднощами у навчанні / Д. Б. Рождественська, В.В. Тарасун // Діагностика і корекція індивідуального розвитку учнів у процесі навчання : збірник наукових праць [Електронний ресурс] // Iнститут психології ім. Г.С. Костюка. - 2002. - С. 59-68. - Режим доступу : http://lib. iitta.gov.ua/view/creators $/=0420=043 \mathrm{E}=0436=0434=0435=0441=0442==0432=0$ $435=043 \mathrm{D}=0441==044 \mathrm{C}=043 \mathrm{~A}==0430=3 \mathrm{~A}==0414=2 \mathrm{E}==0411=2 \mathrm{E}=3 \mathrm{~A}=3 \mathrm{~A} \cdot \mathrm{html}$

14. Смирнова Е.Е. Содержание понятия «психологическая культура педагога» и пути ее формирования в системе повышения квалификации / Е. Е. Смирнова // Вестник Новгородского государственного университета. - 2010. - № 58. - С. 76-79.

15. Таранченко О.М. Диференційоване викладання в інклюзивному класі : навчально-методичний посібник / О. М. Таранченко, Ю.М.Найда // [За загальною редакцією Колупаєвої А.А.]. — К. : Видавнича група «АТОПОЛ», 2012. — 120 с. — (Серія «Інклюзивна освіта»).

16. Чепелєва Н. В. Психологічна культура майбутнього вчителя / Н. В. Чепелєва. — К. : Т-во «Знання» УРСР, 1989. - 32 с.

17. Шаталов В. Ф. Педагогическая проза: Из опыта работы школ г. Донецка / В. Ф. Шаталов. — М. : Педагогика, 1980. - 96 с.

18. Шаталов В.Ф. Куда и как исчезли тройки: Из опыта работы школ г. Донецка / В. Ф. Шаталов // Предисл. В. В. Давыдова. - М. : Педагогика, 1979. - 136 с.

19. Шаталов В. Ф. Точка опоры / В.Ф. Шаталов. - М. : Педагогика, 1987. - 160 с.

Аннотация. В статье анализируются факторы, которые лежали в основе успешности работы педагогов-новаторов, высказывается предположение, что эффект преодоления школьной неуспеваемости педагогами-новаторами достигался не столько за счет эффективных новых методик, сколько был следствием высокой психологической культуры педагогов-новаторов. При этом психологическая культура понимается как интегральное сочетание психологической компетентности, иенностно-смыслового компонента (отнотение к людям, миру, своей деятельности) и когнитивной составляющей (развитие познавательных проиессов и рефлексии). Доказывается, что все новаторы были психологически и педагогически компетентными, верили в способность каждого ребенка хорошо учиться, любили своих воспитанников, постоянно самосовершенствовались и стимулировали развитие учащихся.

Ключевые слова: психологическая культура, школьная неуспеваемость, педагоги-новаторы, эффективность обучения. 
Abstracts. This article analyzes the factors that underlie the success of teachers-innovators, speculate that the effect of overcoming school failure by teachers-innovators achieved not only through effective new techniques, as was the result of high psychological culture of teachers-innovators. This psychological culture understood as integral combination of psychological competence, value-semantic component (towards people of the world, their own activities) and cognitive component (development of cognitive processes and reflection. It is proved that all innovators were psychologically and educationally competent, believed in the ability of every child to study, love their pupils, and stimulated the development of himself and students.

Keywords: psychological culture, school failure, teachers-innovators, effectiveness of training. 